Jurnal Konstruksi Hukum | ISSN: XXXX | E-ISSN: XXXX Vol. 1, No. 1, September 2020 Hal. 1-6| Available online at https://www.ejournal.warmadewa.ac.id/index.php/jukonhum DOI: https://doi.org/10.22225/jkh.1.1.2120.1-6

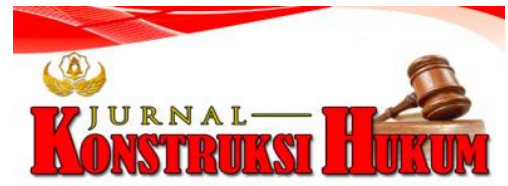

\title{
TINJAUAN YURIDIS TERHADAP KUASA YANG DIBERIKAN WNI KEPADA WNA UNTUK MENGALIHKAN HAK ATAS TANAH
}

\author{
A.A. Gede Cahya Pratama, I Nyoman Sumardika, I Wayan Arthanaya \\ Fakultas Hukum, Universitas Warmadewa, Denpasar-Bali, Indonesia
}

\begin{abstract}
Abstrak
Lembaga perwakilan mempunyai suatu ciri yang unik karena pihak melakukan tindakan dan penerima akibat hukumnya adalah dua orang yang berlainan. Itulah sebabnya kuasa sebagai bagian dari lembaga hukum perwakilan dalam praktiknya banyak menimbulkan masalah. Dalam hal pemberian kuasa, yang dilakukan berbeda dari pemberian kuasa biasa, dimana pemberian kuasa yang dimaksudkan ialah dilakukan oleh Warga Negara Indonesia (selanjutnya disebut WNI) kepada Warga Negara Asing (selanjutnya disebut WNA) untuk mengalihkan tanah WNI kepada pihak yang ingin membeli tanah yang telah dikuasakannya itu. Dalam kajian ada dua isu hukum yang ditelaah, yaitu bentuk pemberian kuasa oleh WNI Kepada WNA terkait pengalihan hak atas tanah dan akibat hukum yang timbul atas pemberian kuasa dari kuasa tersebut. Hasil penelitian ini menunjukan bahwa pemberian kuasa tidak berbentuk tindakan penuh terhadap apa yang diberikan pemberi kuasa kepadanya, melainkan suatu tindakan kuasa yang hanya sebagai perpanjangan tangan dari si pemberi kuasa atas apa yang pemberi kuasa kehendaki sesuai dengan Pasal 1792 BW. Akibat Hukum yang timbul atas pemberian kuasa dari WNI kepada WNA oleh karena itu segala sebab dan akibat yang timbul perjanjian kuasa menjadi tanggung jawab sepenuhnya dari pemberi kuasa dalam batasan-batasan yang telah ditentukan. Setiap warga Negara mestinya menaruh perhatian serius dengan merealisasikan dalam tindakan ketetapan hati untuk tidak memindahkan hak-hak kepemilikan tersebut kepada pihak lain di luar WNI. Hal ini dapat didukung dengan banyaknya kajian-kajian ilmiah yang diluncurkan, termasuk terkait upaya antisipatif terhadap hal tersebut.
\end{abstract}

Kata Kunci: Hak atas Tanah; Perjanjian, Pemberi Kuasa; Penerima Kuasa

\begin{abstract}
A representative institution takes possession of a unique characteristic since the legal consequences born by both the principal and the attorney in fact are divergent. This is why the attorney as a part of a representative legal institution in practice causes many problems. In terms of granting the attorney, what is done in practice is in opposition to the ordinary granting of power, in that, the intended attorney is given by an Indonesian citizen (hereinafter is WNI) to a foreign citizen (hereinafter is WNA) to transfer the title to land of an Indonesian citizen to the party who wants to purchase the land that has been controlled. In the study, there are two legal issues examined, the form of granting the attorney by Indonesian citizens to foreign nationals regarding the transfer of title to land and the legal consequences arising from the granting of the attorney. The results indicate that the granting of attorney is not in the form of a full action against what is granted to the attorney in fact by principal, but an act of attorney which is only an extension of the hand of the principal over what the principal wants in accordance with Article 1792 BW. The legal consequences arising from granting attorney from Indonesian citizens to foreign nationals are in full responsibility of the principal within predetermined limits. Every citizen needs pay serious attention to realising in the real actions the determination of not to transfer their ownership rights of lands to other parties outside of Indonesian citizens. This can be supported by the conducting a number of scientific studies related to the ownership of lands, including those related to anticipatory efforts towards it.
\end{abstract}

Keywords: Land rights; Agreement; Principal; Attorney in Fact

\section{PENDAHULUAN}

Dalam sistem pemerintahan, terdapat suatu ciri yang unik yang dimiliki oleh lembaga perwakilan karena antara yang bertindak dan yang menerima, akibat hukumnya adalah dua pihak yang berlainan. Itulah sebabnya kuasa sebagai bagian dari lembaga hukum perwakilan dalam praktik banyak menimbulkan masalah, oleh itu sudah umum bahwa seseorang tidak merumuskan kuasa yang telah diberikan secara teliti dan terperinci secara jelas sehingga menimbulkan ruang bagi penerima kuasa 
untuk melaksanakan paling tidak sebagian dari kuasa itu menurut apa yang dianggap baik dan yang menurut anggapan si penerima kuasa masih termasuk dalam kuasa yang diterimanya. Yang namanya "anggapan" tidak selalu sesuai dengan kenyataan yang ada. Kalau kekurangan itu disadari oleh pembuat undang-undang mestinya pembuat undang-undang menyediakan ketentuan untuk menampung kekurangan seperti itu (Satrio, 2018).

Kuasa bisa dikatakan sebuah pernyataan yang dimana seseorang memberikan sebuah kewenangan kepada orang maupun badan yang berlaku di Negara Indonesia untuk dan atas namanya melakukan perbuatan hukum (Latumeten, 2017). Pengertian atas nama dapat disimpulkan sebagai sebuah pernyataan yang dimana seseorang tersebut mengikatkan dirinya terhadap orang lain dimana melangsungkan kepentingan pemberi kuasa itu sendiri. Dengan perkataan lain, penerima kuasa dapat dan berwenang bertindak atau berbuat seolah-olah ia adalah orang yang memberi kuasa.

Dalam hal pemberian kuasa, Pasal 1792 BW memberikan batasan bahwa kuasa yang diberikan kepada orang lain tersebut adalah sepenuhnya untuk melakukan kepentingan orang yang memberikan kuasa untuk dan atas namanya. Orang yang memberikan kuasa dapat melakukan tindakan secara sepihak sehingga perjanjian tersebut dinamakan perjanjian sepihak, dimana orang yang menerima kuasa untuk dan atas nama pemberi kuasa tidak diwajibkan untuk menandatangani perjanjian tersebut.

Walaupun disebutkan sebagai perjanjian sepihak dalam pasal 1313 BW suatu perjanjian merupakan perbuatan hukum di mana satu orang mengikatkan dirinya terhadap orang lain atau lebih, sehingga walaupun penerima kuasa tidak ikut menandatangani perjanjian tersebut tetapi adanya tanggung jawab moral untuk melaksanakan apa yang dikuasakan kepadanya, maka ada kesepakan antara kedua belah pihak tersebut (Sugiyarti, 2008). Namun scara otentik akta harus ditandatangi oleh kedua belah pihak yang sepakat untuk mengikatkan dirinya satu sama lain. Hal ini erat kaitannya dengan pasal $1338 \mathrm{BW}$ bahwa masing-masing pihak yang mengikatkan dirinya harus memahami isi perjanjian yang dibuat sebelum menandatangani akta perjanjian itu (Meliala, 2008).

Mengacu pada konsep Satrio (2018) inti dari kuasa ialah adanya "kewenangan", dalam hal ini, sebuah kewenangan adalah ciri suatu hak. Kewenangan sama halnya dengan sekelompok kewenangan. Satrio menyimpulkan bahwa ini nanti mempunyai konsekuensi-konsekuensinya. Pemberian kuasa merupakan tindakan memberikan suatu kewenangan (volmach) yang pada asasnya bisa dilakukan dengan tindakan hukum sepihak, artinya untuk timbul akibat hukum yang dikehendaki cukup dilakukan oleh satu pihak saja (Satrio, 2018).

Dari hasil penelusuran awal dan praktik terjadi pemberian kuasa dari Tuan Anak Agung Alit Suening Merta kepada Mr. James Frederick Snelling sebagai WNA. Pemberian kuasa ini didasari karena pada awal mula Mr. James Frederick ingin membeli sebidang tanah, namun ia tidak ingin menurunkan hak atas tanah tersebut menjadi hak pakai karena menurut pemahamannya tanah tersebut bisa ditarik sewaktu-waktu oleh pemerintah jika pemerintah menghendakinya. Berangkat dari pemahaman tersebut Mr. James Frederick melakukan peminjaman nama terhadap WNI dengan diikatnya sebuah perjanjian. Dalam perjanjian tersebut, uang yang dipergunakan untuk membeli tanah tersebut adalah miliknya dan jika sertifikat telah terbit maka asli sertipikat diserahkan kepadanya.

Telaah ilmiah terhadap tindakan pemindahan kepemilihan hak atas tanah oleh WNI kepada WNA telah sering diluncurkan dan kejian kali ini bukanlah kajian yang pertama. Pada kajian sebelumnya, ditemukan bahwa dalam praktik pelaksanaan ketentuan Undang-Undang yang berlaku di Indonesia bahwa tanah di Indonesia hanya boleh dimiliki oleh WNI, sering sekali dilanngar melalui penyelundupan hukum seperti penggunaan perjanjian Nominee (Alhumami, 2016). WNA hanya diberi ijin memanfaatkan tanah di Indonesia dengan hak-hak, seperti Hak Guna Usaha (HGU), Hak Guna Bangunan (HGB), Hak Pakai, dan Hak Sewa Bangunan dan pelanggaran dengan penggunaan perjanjian Nominee merupakan perjanjian yang batal dan tidak sah (Kindangen, 2019). Hak-hak yang dapat diperoleh WNA atas tanah di Indonesia pun hanya merupakan harus didaftarkan berdasarkan Peraturan Menteri Agraria No 1 Tahun 1966 tentang Pendaftaran Hak Pakai dan Hak Pengelolaan (Mahadewi, 2019). Sanksi hukum bagi WNA yang memiliki rumah tempat tinggal atau hunian di Indonesia tanpa mengikuti prosedur yang telah ditentuan oleh hukum diatur dalam Pasal 26 ayat (2) Undang-Undang Pokok Agraria (UUPA). Selain itu perhatian pemerintah masih diperlukan untuk mengevaluasi kebijakan tentang rumah tempat tinggal bagi orang asing (Kusumawati, 2019). 
Namun demikian, penggunaan perjanjian Nominee memang diperbolehkan asal memenuhi syarat objektif yang ditentukan Undang-Undang dan hukumannya ialah perjanjian tersebut batal demi hukum (Pramana dkk., 2020).

Berdasarkan uraian latar belakang penelitian ini mengkaji tentang: bagaimanakah bentuk pemberian kuasa yang dilakukan oleh WNI kepada WNA terkait dengan pengalihan hak atas tanah? Apakah akibat hukum yang timbul atas pemberian kuasa dari WNI kepada WNA tersebut? Adapun tujuan dari penelitian ini, yaitu untuk mengetahui bentuk pemberian kuasa yang dilakukan oleh WNI kepada WNA terkait dengan pengalihan hak atas tanah dan untuk mengungkap akibat hukum yang timbul atas pemberian kuasa dari WNI kepada WNA tersebut.

\section{METODE PENELITIAN}

Dalam penelitian ini tipe penelitian yang digunakan adalah penelitian hukum Normatif yang merupakan sebuah metode penelitian hukum yang menggunakan data sekunder dan kajian-kajian pustaka. Penelitian ini dipergunakan untuk mengidentifikasi kaidah dan norma-norma hukum positif yang berlaku di Indonesia dengan menggunakan bahan-bahan kepustakaan yang ada maupun peraturan perundang-undangan yang berlaku.

Dalam penelitian ini bahan hukum bersumber dari studi dokumen (kepustakaan). Adapun jenis bahan hukum dalam penelitian ini adalah sebagai berikut:

1. Bahan Hukum Primer

Bahan hukum primer yang penulis pergunakan adalah peraturan perundang-undangan yaitu dari hukum positif Indonesia yang diambil dari KUHP, UUPA, pendasaran itikad baik dan peraturan pemerintah tentang pendaftaran hak atas tanah.

2. Bahan Hukum Sekunder

Bahan hukum sekunder berupa buku-buku hukum, jurnal-jurnal hukum, surat kabar dan juga artikel-artikel dari kajian internet yang berkaitan dengan penerbitan Akta Kuasa yang diberikan terhadap WNA dalam hal untuk mengalihkan hak atas tanah yang dimiliki oleh WNI.

3. Bahan Hukum Tersier

Ensiklopedia, kamus hukum, kamus Bahasa, dan bahan ilmu lain yang terkait menjadi bahan hukum tersier yang penulis pergunakan, juga ditunjang dengan hasil wawancara dengan pihakpihak yang memahami terhadap tulisan yang penulis tulis.

Teknik atau cara memperoleh bahan hukum yang digunakan adalah semua bahan-bahan yang sudah di dapat dalam penulisan ini, selanjutnya dianalisis dan disusun secara sistematis dengan menggunakan Interpretasi Hukum secara deduktif yaitu penerapan norma kedalam kasus-kasus dan induktif analitik yaitu kasus-kasus digeneralisir menjadi norma-norma.

\section{HASIL DAN PEMBAHASAN}

\section{Bentuk Pemberian Kuasa yang Dilakukan oleh WNI kepada WNA Terkait dengan Pengalihan Hak atas Tanah}

Kekuatan pembuktian antara akta otentik dan akta dibawah tangan memiliki perbedaan yang sangat besar. Walaupun dalam hukum acara perdata di Indonesia tetap mengakui surat sebagai alat bukti sah di pengadilan, akta dibawah tangan memiliki kekuatan pembuktian yang lebih lemah dibandingkan akta otentik. Pembuktian akta otentik tidak dapat disangkal oleh para pihak yang membuatnya dikarenakan akta tersebut dibuat dihadapan pejabat yang berwenang yaitu Notaris.

Sahnya suatu akta atau perjanjian harus memenuhi sayarat sahnya sebuah perjanjian yang sesuai dengan 4 syarat sah dalam pasal $1320 \mathrm{BW}$ :

1) Sepakat mereka yang mengikatkan dirinya;

2) Kecakapan untuk membuat suatu perikatan;

3) Suatu hal tertentu;

4) Suatu sebab yang halal.

Pada Nomor 1 dan 2 disebut dengan syarat subjektif, dimana jika salah satu syarat tersebut tidak terpenuhi maka akibat hukum yang timbul yaitu dapat di batalkan. Sedangkan da la m Nomor 3 dan 4 disebut dengan syarat obyektif, dimana jika salah satu syarat tersebut tidak terpenuhi maka akibat hukum yang timbul yaitu batal demi hukum atau dengan kata lain perjanjian tersebut tidak pernah ada (Darsana, 2019). Selama akta atau perjanjian dibawah tangan memenuhi 
empat syarat sah yang tertuang didalam pasal tersebut diatas maka akta atau perjanjian tersebut adalah sah secara hukum positif di Indonesia.

Akta otentik dibuat dalam bentuk yang udah di tentukan dalam perundang-undangan yang mana dibuat dihadapan pejabat umum atau Notaris, akan tetapi juga dapat dibuat oleh PPAT. Tulisan dibawah tangan atau juga disebut akta dibawah tangan dibuat atas dasar kesepakatan para pihak dalam hal ini dibuat dihadapan para pihak saja dan tidak dengan perantara pihak ketiga sebagai pejabat umum atau Notaris, yang mana bertujuan untuk sebagai alat bukti (Adjie, 2018). Dalam hal ini akta otentik merupakan alat bukti yang sempurna, dimana akta otentik dibuat oleh pejabat umum yang mengetahui tentang hukum akan tetapi akta otentik dapat disangkal oleh pihak ketiga yang dimana merupakan pembuktian dengan kekuatan bebas dimana penilaiannya diserahkan pada pertimbangan hakim.

Dalam kasus yang saya angkat dalam hal ini Tuan Anak Agung Alit Suening Merta memberikan kuasa terhadap WNA yaitu Mr. James Frederick Snelling dengan Akta Kuasa Otentik yang dibuat dihadapan Notaris, dimana WNA ini bertindak sesuai dengan Identitas dan kecakapannya untuk melakukan perbuatan hukumnya pada Akta Kuasa tersebut. Berdasarkan adanya Akta Kuasa penerima kuasa hendak mengalihkan tanah kepada pihak ketiga yang mana berstatus WNI.

Dengan berjalannya waktu yang WNA tersebut mendapatkan pembeli terhadap objek tanah tersebut, dimana ia bertindak dengan akta kuasa dalam sebuah akta jual beli dalam hal mengalihkan hak atas tanah kepada pihak yang baru yaitu WNI.

Dalam Kasus diatas pertama yang akan dibahas yaitu mengenai fakta hukum dimana WNA berkeinginan mengunakan akta kuasa yang dibuat secara notariil guna mengalihkan hak atas tanah dari WNA. Pemberian kuasa diatur dalam pasal 1792 BW, yang dimana kuasa sama halnya dengan sebuah perjanjian (Subekti \& Tjitrosudibio, 2008).

Tindakan pemberian kuasa bukan berarti tindakan penuh terhadap apa yang diberikan pemberi kuasa kepadanya, melainkan suatu tindakan kuasa hanya sebagai perpanjangan tangan dari si pemberi kuasa atas apa yang pemberi kuasa kehendaki. Dalam hal ini penerima kuasa menjalankan sesuai dengan apa yang ada dalam perjanjian kuasa untuk bertindak sebagai perwakilan dari pemberi kuasa terkait dengan penandatanganan akta jual beli.

\section{Akibat Hukum yang Timbul a tas Pemberian Kuasa dari WNI kepada WNA}

Karena pemberi kuasa merupakan suatu tindakan hukum, maka perlu diperhatikan syarat-syarat yang berkaitan dengan tindakan hukum. Sekalipun tidak ada mengatur tentang hal ini, namun dari ketentuan- ketentuan yang ada di dalam B. W. bahwa agar suatu tindakan hukum mempunyai akibat hukum sebagai yang dikehendaki, orang yang bertindak harus cakap dan wewenang untuk bertindak. Ketentuan pasal 1320 B.W. bisa dipakai sebagai acuan, sekalipun pemberian kuasa bisa terjadi melalui tindakan hukum sepihak (Subekti \& Tjitrosudibio, 2008).

Bentuk pemberian kuasa yang terdapat dalam pasal 1793 BW antara lain: pemberian kuasa dengan Akta otentik, pemberian kuasa surat atau akta di bawah tangan, pemberian kuasa dengan surat biasa, pemberian kuasa diam-diam dan atau pemberian kuasa lisan. Penerima kuasa adalah orang atau person, yang diberikan kewenangan oleh pemberi kuasa untuk bertindak mewakili kepentingan pemberi kuasa melakukan tindakan hukum, termasuk mengadakan hubungan hukum kepada pihak ketiga, untuk dan atas nama pemberi kuasa karena akibat hukum yang muncul dari di kuasa menimpa (atau jatuh kepada) pemberi kuasa, yang bisa merupakan akibat hukum yang sangat besar, maka sudah bisa diduga pemberi kuasa tidak akan sembarangan memilih orang yang akan diberikan kuasa. Dapat dikatakan bahwa seseorang yang diangkat (ditunjuk) sebagai kuasa adalah orang kepercayaan pemberi kuasa (Satrio, 2018).

Jadi kuasa itu harus dilaksanakan dengan itikad baik oleh penerima kuasa, dan karenanya adalah sangat tidak patut kalau kuasa itu terhadap si pemberi kuasa dilaksanakan bertentangan dengan kehendak pemberi kuasa, sekalipun kuasanya tidak dengan jelas mengatur batas-batas kewenangan yang diberikan kepadanya. Kalau, sekalipun ia sudah diberikan kewenangan untuk bertindak mewakili pemberi kuasa; namun demikian, ia tahu bahwa pemberi kuasa mau melakukan sendiri tindakan hukum untuk mana telah diberikan kuasa kepada si penerima kuasa, si penerima kuasa harus mendahulukan kehendak pemberi kuasa. Kalau penerima kuasa tahu, bahwa pemberi 
kuasa sedang berunding melaksanakan penjualan benda, untuk nama si kuasa diberikan kewenangan untuk menjualnya atas nama pemberi kuasa, maka si kuasa tidak boleh mendahului menjual kepada calon pembeli, dengan tindakan mana ia memotong perundingan yang sedang berlangsung antara calon pembeli dengan pemberi kuasa. Kepatutan tidak membenarkan penerima kuasa untuk bersaing dengan pemberi kuasa, melakukan tindakan untuk hal mana ia diberikan kuasa. Hal itu berarti bahwa kalau penerima kuasa mempunyai kepentingan atas pelaksanaan kuasa yang diberikan kepadanya, ia tetap wajib mendahulukan kepentingan pemberi kuasa.

Akibat hukum terhadap tanah yang dialihkan yaitu dalam UUPA ditetapkan bahwa yang berhak memiliki tanah hak milik di Negara Indonesia adalah WNI. WNA tidak diperbolehkan memiliki Hak Milik dan pemindahan hak milik kepada WNA dilarang dengan ancaman batal demi hukum.

\section{SIMPULAN DAN SARAN}

\section{Simpulan}

Bentuk pemberian kuasa kepemilikan hak atas yang dilakukan oleh WNI kepada WNA merupakan sebuah perjanjian di mana seseorang membuat kesepakatan untuk memberikan kuasa kepada orang lain, sebagai penerima kuasa, atas namanya untuk menyelenggarakan suatu urusan. Tindakan pemberian kuasa bukan berarti tindakan penuh terhadap apa yang diberikan pemberi kuasa kepadanya, melainkan suatu tindakan kuasa yang hanya sebagai perpanjangan tangan dari si pemberi kuasa atas apa yang pemberi kuasa kehendaki sesuai dengan Pasal 1792 BW.

Akibat Hukum yang timbul atas pemberian kuasa dari WNI kepada WNA bahwa penerima kuasa bertindak untuk dan atas nama pemberi kuasa; oleh karena itu, segala sebab dan akibat yang timbul dari perjanjian kuasa menjadi tanggung jawab sepenuhnya pihak pemberi kuasa dalam batasan-batasan yang telah ditentukan.

\section{Saran}

Kepemilikan hak atas tanah sebagaimana di atur oleh pemerintah hanya diperbolehkan bagi WNI maka setiap warga Negara mestinya menaruh perhatian serius dengan merealisasikan dalam tindakan ketetapan hati untuk tidak memindahkan hak-hak kepemilikan tersebut kepada pihak lain di luar WNI. Terkait hal tersebut, kajian-kajian di masa mendatang perlu mengkaji tentang efektivitas ketentuan Undang-undang yang mengatur tentang larangan pemindahan hak kepemilikan atas tanah kepada WNA serta upaya antisipatif yang harus dilakukan agar tindakan pemindahan hak atas tanah dari WNI kepada WNA tidak terjadi karena berbagai alasan, termasuk alasan ekonomis.

\section{DAFTAR PUSTAKA}

Adjie, H. (2018). Hukum Notaris Indonesia (Tafsir Tematik terhadap UU No.30 Tahun 2004 tentang Jabatan Notaris) (Kelima). PT. Refika Aditama.

Alhumami, K. (2016). Melindungi Kedaulatan Tanah Indonesia dari Penguasaan Orang Asing: Tinjauan atas Putusan Praperadilan Nomor 07/PID.Prap/2015/PN.DPS. Jurnal RechtsVinding, $5(1), 51-67$.

Darsana, I. M. P. (2019). Populisme Menghancurkan Demokrasi (1st ed.). Serat Ismaya.

Kindangen, A. P. (2019). Tinjauan Yuridis terhadap Kasus Warga Negara Asing yang Memiliki Hak Milik atas Tanah melalui Perjanjian Nominee Menurut Undang-Undang Pokok Agraria No. 5 Tahun 1960. Lex Et Societatis, 7(2), 55-62.

Kusumawati, D. (2019). Pengaturan Sanksi Hukum Terhadap Pemilikan Rumah Tempat Tinggal bagi Orang Asing di Indonesia. Jurnal Hukum Prasada, 6(1), 59-71.

Latumeten, P. E. (2017). Reposisi Pemberian Kuasa dalam Konsep "Volmacht dan Lastgeving" berdasarkan Cita Hukum Pancasila. Jurnal Hukum \& Pembangunan, 47(1), 1-37.

Mahadewi, K. J. (2019). Tinjauan Yuridis Karakteristik Penggunaan Hak Pakai dalam Kepemilikan Apartemen oleh Warga Negara Asing di Indonesia Jurnal Gema Keadilan Jurnal Gema Keadilan. Jurnal Gema Keadilan, 6(2), 184-195.

Meliala, D. S. (2008). Perjanjian Pemberian Kuasa (Pertama). Nuansa Aulia.

Pramana, K. Y., Adnyani, N. K. S., \& Sudiatmaka, K. (2020). Tinjauan Yuridis Pembatasan Penguasaan Tanah oleh Warga Negara Asing berdasarkan UU No. 5 Tahun 1960 tentang Peraturan Dasar Pokok-Pokok Agraria. E-Journal Komunitas Yustisia Universitas Pendidikan 
Ganesha, 3(1).

Satrio, J. (2018). Perwakilan dan Kuasa. PT. Rajagrafindo Persada.

Subekti, \& Tjitrosudibio. (2008). Kitab Undang-Undang Hukum Perdata. Pradnya Paramita.

Sugiyarti, G. (2008). Pelaksanaan Kuasa Menjual dalam Kaitannya dengan Perjanjian Utang Piutang di Wilayah Jakarta Selatan. Universitas Diponegoro.

Undang-Undang Republik Indonesia Nomor 5 Tahun 1960 tentang Peraturan Dasar Pokok-Pokok Agraria.

Undang-Undang Republik Indonesia Nomor 12 Tahun 2006 tentang Kewarganegaraan Republik Indonesia.

Kitab Undang-Undang Hukum Perdata (KUHPerdata) 